DOI: $10.1515 /$ pts-2017-0001

PHYSICAL AND TECHNICAL ENERGY PROBLEMS

\title{
INFLUENCE OF PERMANENT MAGNET CHARACTERISTIC VARIABILITY ON THE WIND GENERATOR OPERATION
}

\author{
O. Kudrjavtsev ${ }^{1}$, A. Kallaste ${ }^{1,2}$, A. Kilk ${ }^{1}$, T. Vaimann ${ }^{1,2}$, S. Orlova ${ }^{1,3}$ \\ ${ }^{1}$ Tallinn University of Technology, Department of Electrical Engineering \\ 5 Ehitajate Str., 19086 Tallinn, ESTONIA \\ ${ }^{2}$ Aalto University, Department of Electrical Engineering and Automation \\ 5A Otakaari Str., 02150 Espoo, FINLAND \\ ${ }^{3}$ Institute of Physical Energetics, \\ 11 Krivu Str., LV-1006, Riga, LATVIA
}

The paper discusses problems concerning the influence of permanent magnet material characteristics on the low-speed permanent magnet generator losses and output characteristics. The variability of the magnet material and its effect on the output parameters of the machine has been quantified. The characteristics of six different grades of neodymium permanent magnets have been measured and compared to the supplier specification data. The simulations of the generator have been carried out using transient finite element analysis. The results show that magnet materials from different suppliers have different characteristics, which have a significant influence on the generator output parameters, such as efficiency and power factor. generator.

Keywords: characteristics variability, permanent magnet, synchronous

\section{INTRODUCTION}

There are several types of generators that can be used for small wind turbines [1]. One of them is the low-speed permanent magnet synchronous generator (PMSG), which is gaining more popularity due to its several advantages. It can be used in wind turbine without gearbox resulting in higher reliability and lower maintenance requirements. The PMSG also offers high efficiency and good power density.

There are several types of permanent magnets (PM) that can be used in generator: Alnico, $\mathrm{SmCo}, \mathrm{NdFeB}$, ferrites [2]. In this study, neodymium magnets are investigated, as they offer relatively high-energy product and have high coercivity.

The SPMG electrical output parameters are strongly influenced by the PM 
characteristics. The variability in PM characteristics can be the result of different aspects, such as wrong usage, demagnetization, wrong manufacturing process, wrong assembly process, etc. In this study, the PM remanence and coercivity variation influence on the generator output parameters are investigated. The investigation is based on the finite element analysis.

The literature that concerns the analysis of fault detection in PM machines is mostly focused on the problems related to demagnetisation [2]-[5]. No importance has been given to variability in the PM characteristics and their effect on the output quantities of the machine.

\section{GENERATOR CHARACTERISTICS}

For this study, a $5 \mathrm{kVA}$ outer rotor PMSG is designed with surface magnets (Fig. 1). The surface magnet design has been chosen because of the simplified assembly process. The main parameters of the machine are given in Table 1. The generator has 32 poles with grade $\mathrm{N} 42 \mathrm{H}$ magnets with the dimensions of 30x10x100 $\mathrm{mm}$.

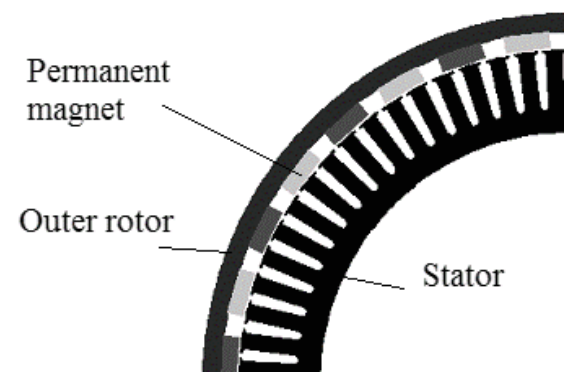

Fig. 1. Cross-section of the designed PM generator with an outer rotor.

Table 1

Generator Parameters

\begin{tabular}{|l|c|c|}
\hline Parameter & Value & Unit \\
\hline Rated power & 5 & $\mathrm{kVA}$ \\
Rotational speed & 200 & $\mathrm{rpm}$ \\
Electromotive force & 255 & $\mathrm{~V}$ \\
Core length & 100 & $\mathrm{~mm}$ \\
Air gap diameter & 448.8 & $\mathrm{~mm}$ \\
Current density & 2.56 & $\mathrm{~A} / \mathrm{mm}^{2}$ \\
Efficiency & 89.2 & $\%$ \\
Number of pole pairs & 16 & - \\
\hline
\end{tabular}

\section{MEASUREMENT PROCESS AND RESULTS}

To study the PM influence on the generator output variables, six different grades of neodymium magnets were selected. For the first five grades three different suppliers of magnets were selected and for the sixth grade two suppliers of magnets 
were selected. Selected magnets were measured with Vibrating Sample Magnetometer (VSM), where the PM hysteresis loop was recorded. Results of the measured magnets are given in Fig. 2 and Fig. 3.

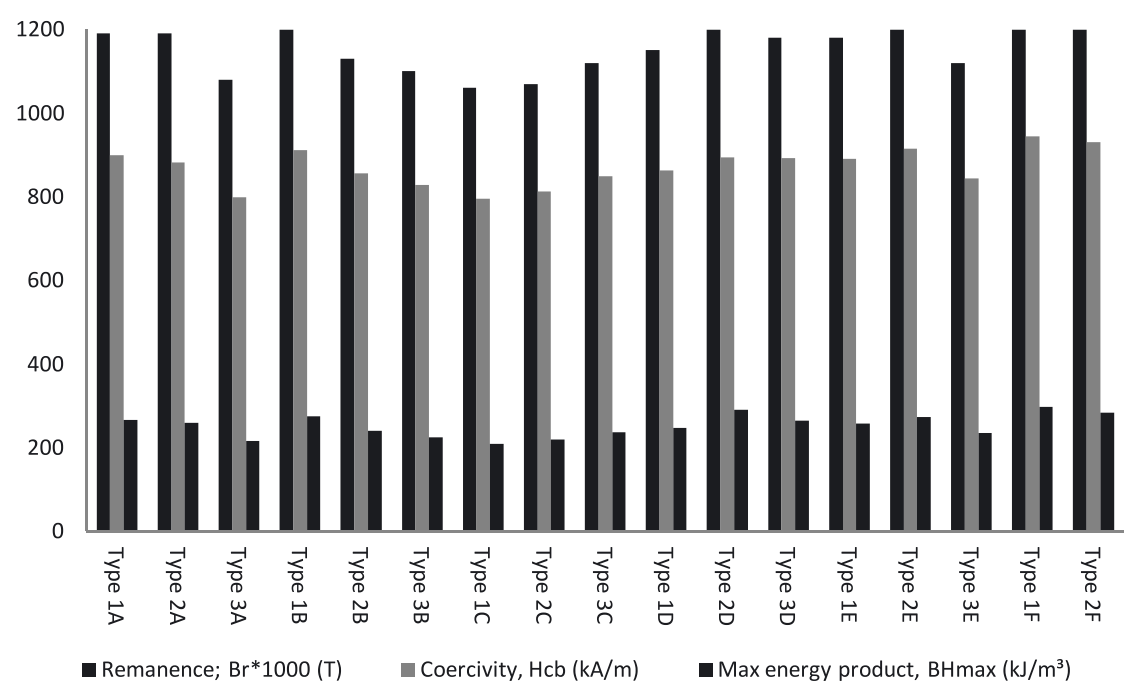

Fig. 2. Comparison graph of permanent magnet characteristics by different suppliers . Type 1A means A grade magnet from the first supplier, type 2A means A grade magnet from the second supplier. The left column indicates the remanence value, middle - the coercivity value and right - the max power product value.

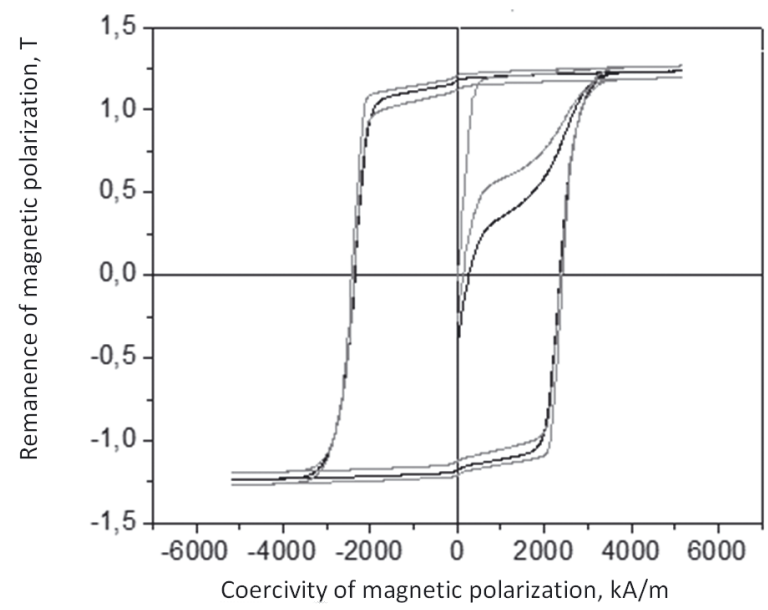

Fig. 3. The curve demonstrates an example of the measuring results made by VSM software for one grade of magnet (Grade A). Different magnet suppliers of the same magnet grade are shown using different hysteresis loops.

For comparison, magnet deviation from its rated value was found. Figure 4 gives the maximum and minimum deviation values of remanence, coercivity and maximum energy product compared to the rated value. The variation of remanence and that of coercivity are approximately $10 \%$; the maximum variation of maximum energy product is $22.96 \%$. 


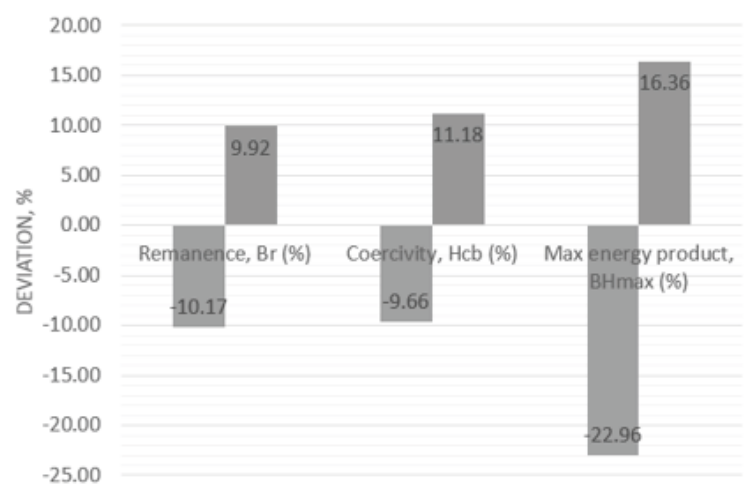

Fig. 4. Measured permanent magnet parameters compared to rated values.

\section{CALCULATION RESULTS}

The machine is designed according to the reference values given in Table 1 . To find the PM characteristic influence on the machine output characteristic, the machine design is kept constant and the magnet remanence and coercivity are changed in $\pm 10 \%$ range from the nominal value. The calculations are carried out so that the machine torque and the output voltage are at the rated value. The calculation has been performed using in-house 2D FEM software.

Performing the calculation, the variation of generator losses was found (Fig. 5). It can be seen that the iron losses have almost a linear response to the magnetic characteristic change and a small nonlinearity comes due to the minor saturation of the core. The copper losses increase when the remanence has a different value from the rated one because of the increase of reactive current in the stator winding.
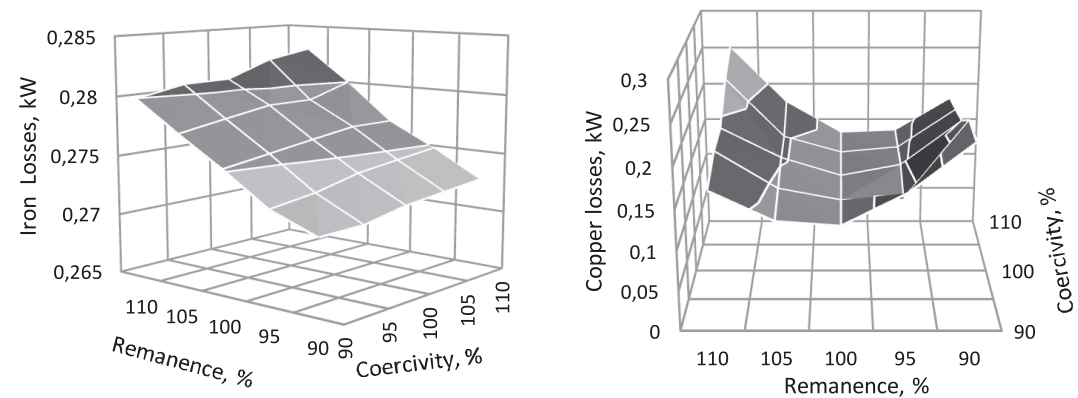

Fig. 5. Calculated variation of iron losses (left) and copper losses (right) as a function of the percentage variation of the remanence and coercivity of the permanent magnet at the rated torque operation of the generator.

The variation of the efficiency and power factor is given in Fig. 6. It can be seen that the efficiency and the power factor decrease when remanence is shifted from the rated value. The reason for such a drop is that the efficiency and power factor are optimal, when remanence is equal to the rated value $(100 \%)$.

The reason of the power factor variation is the air gap flux density variation, which is influenced by the remanence of the magnet, and influences the machine 
electromotive force (EMF). When remanence is smaller than the rated value, the production of EMF will also be smaller. Similarly, when remanence is larger than the rated value, the production of EMF will be greater. The efficiency and the copper losses both depend on the power factor. For that reason, the power factor and the efficiency curves have similar shapes and the copper loss opposite shape.
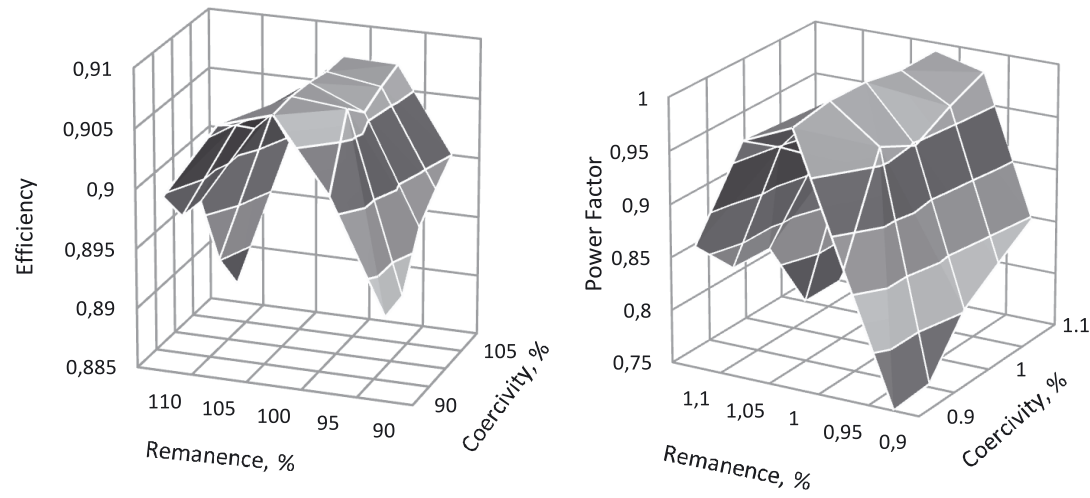

Fig. 6. Calculated variation of efficiency (left) and power factor (right) as a function of the percentage variation of the remanence and coercivity of the permanent magnet at the rated torque operation of the generator.

\section{PERMANENT MAGNET DEMAGNETIZATION}

One of the most critical parts of the PM generator is permanent magnets. Considering the needs of this PMSG with an outer rotor, the $\mathrm{NdFeB}$ magnets were designed to be used in this machine. The permanent magnet parameters are highly dependent on the temperature. The magnet type $\mathrm{N} 42 \mathrm{H}$ was chosen to have high operational maximum temperature of $180^{\circ} \mathrm{C}$.

The maximum load of the generator corresponds to the short-circuit conditions. Due to the armature reaction influence and significant decrease of flux density in the magnets during the short-circuit situation, the risk of demagnetization occurs.

The working point of the magnet is defined by the length of the magnetic path, which should be passed by the magnetic flux, and eventually the value of the current producing opposing flux. In other words, it is defined by the construction of the generator and the armature reaction magnetic flux density that emerges when the generator is loaded. The work or load point of the magnet can be found using Ampere's law:

$$
\int H d l=n I,
$$

where $H$ describes the magnetic field strength, $l$ - the length of the magnetic path, $I$ is the current and $n-$ a number of turns.

As the current is missing in no-load operation, we have to specify magnetic field strength in the magnet, which is non-zero and opposite to the magnetic field strength along the rest of the magnetic path [6].

Partial demagnetization of permanent magnet means that the demagnetization curve drops comparing to its original position. 
The fact that the demagnetization curve depends on the temperature of the magnet should be taken into account when using the magnet either in modelling or in constructing the wind generator. Figure 7 demonstrates the test results of temperature rise of the generator. Three curves indicate the temperature of the stator winding. The temperature of the permanent magnet can be approximately estimated from the stator winding temperature. The permanent magnet temperature will be about $20{ }^{\circ} \mathrm{C}$ lower than the stator winding temperature due to better cooling conditions.

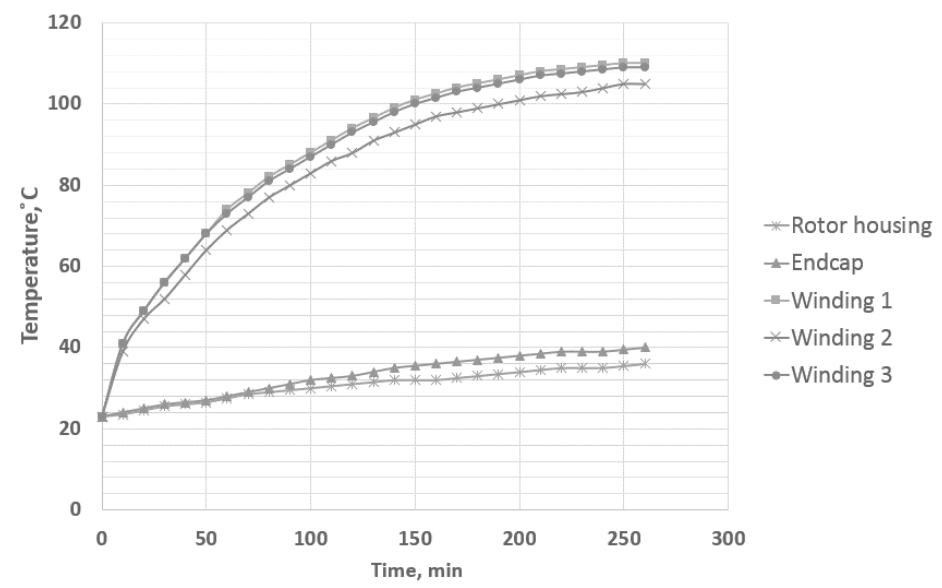

Fig. 7. Transient curves of temperature rise of the studied PM synchronous generator with an outer rotor. Temperature of winding 1 and that of winding 3 were measured in the slot centre. The temperature of winding 2 was measured in the end-winding part.

The simulation of short-circuit condition was performed for the generator with different magnet characteristics. The variation in permanent magnet characteristics was considered according to measurements made in Section 3. The remanence and coercivity varied withn the range of $90 \%-110 \%$ of the rated value. Figure 8 shows the calculated demagnetization curves for remanence and coercivity equal to $90 \%$ of the rated values. The minimum remanence during the short-circuit is $0.24 \mathrm{~T}$; therefore, demagnetization is not present.

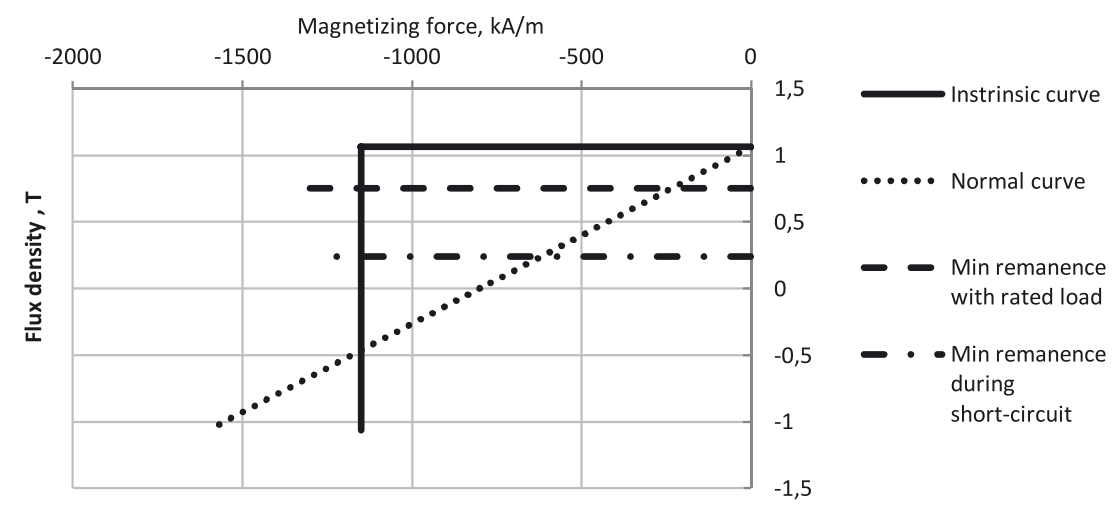

Fig. 8. Operating parameters of $\mathrm{N} 42 \mathrm{H}$ grade magnet when remanence and coercivity are reduced by $10 \%$ of the rated value. 
Figure 9 shows the calculated demagnetization curves for remanence and coercivity equal to $100 \%$ of the rated values. The minimum remanence during the short-circuit is $0.52 \mathrm{~T}$; therefore, demagnetization is not present.

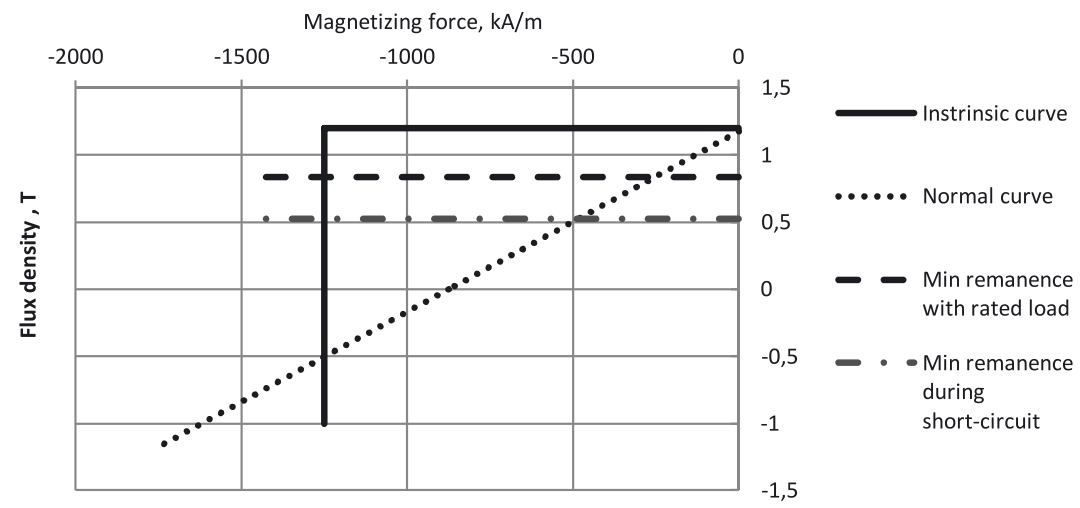

Fig. 9. Operating parameters of $\mathrm{N} 42 \mathrm{H}$ grade magnet when remanence and coercivity are equal to the rated values.

Figure 10 shows the calculated demagnetization curves for remanence and coercivity equal to $110 \%$ of the rated values. The minimum remanence during the short-circuit is $0.56 \mathrm{~T}$; therefore, demagnetization is not present.

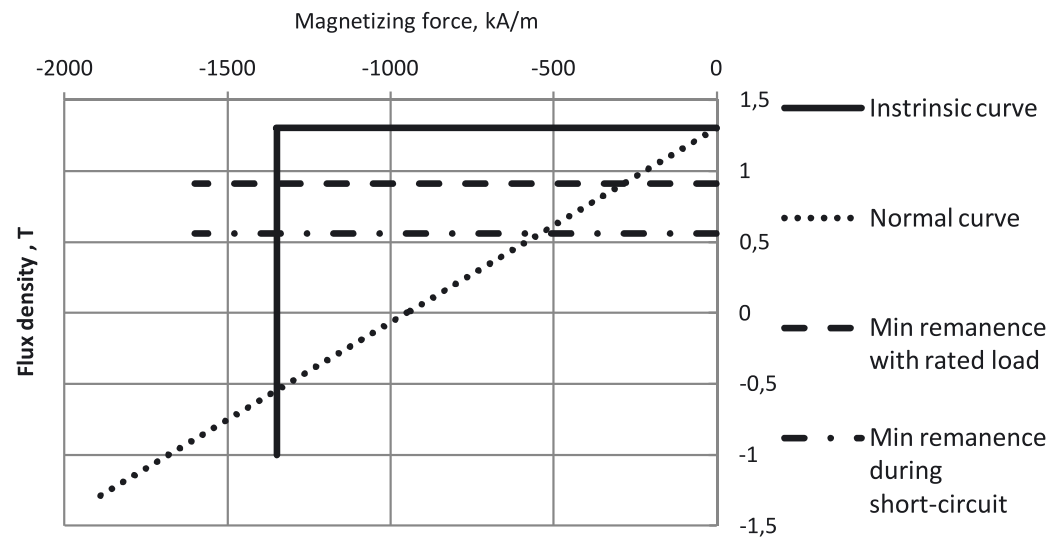

Fig. 10. Operating parameters of $\mathrm{N} 42 \mathrm{H}$ grade magnet when remanence and coercivity are increased by $10 \%$ of the rated value.

When remanence and coercivity are relatively high, the minimum flux density is getting higher, reducing the risk of demagnetization of permanent magnet.

The calculation for the studied PMSG with an outer rotor has shown that the armature reaction is not too strong to demagnetize the magnets and the lowest flux density in the magnet during the short circuit is about $0.7 \mathrm{~T}$ at $100{ }^{\circ} \mathrm{C}$ and at rated values of remanence and coercivity.

To reduce the risk of demagnetization, the proper design of rotor should be considered. The location of magnets should be chosen in the coolest region of the 
machine. In the conditions of PMSG with an outer rotor, the magnets are relatively well cooled by the flow of air through the ribs on the outer surface of the rotor.

\section{CONCLUSIONS}

In the present research, the effect of PM characteristic variation on the generator output characteristic has been studied. For this purpose, various PM materials have been measured. The measuring results have shown a significant variation in magnet characteristics.

This PM variation has been taken into account during the generator calculations and its influence on the machine losses and efficiency has been quantified. The presented calculations have demonstrated a significant influence of the permanent magnet remanence on the machine power factor. As the power factor changes, it also strongly affects the machine efficiency and copper losses.

The influence of permanent magnet characteristic variation on demagnetization has been investigated. The demagnetization curves have been calculated and analysed for remanence and coercivity variation of $90 \%-110 \%$. The results have shown that demagnetization does not appear in all cases. The calculations have demonstrated that the risk of demagnetization is getting higher when remanence and coercivity decrease compared to the rated value.

\section{ACKNOWLEDGEMENTS}

The present research has partially been supported by the Estonian Research Council under Grants PUTJD134 and PUT1260.

\section{REFERENCES}

1. Kudrjavtsev, O., \& Kilk, A. (2012). Study and verification of a slow speed PM generator with outer rotor for small scale wind turbines. In Proceedings of Electric Power Quality and Supply Reliability Conference (PQ), 11-13 June 2012 (pp. 1-6). Tartu, Estonia: IEEE.

2. Kallaste, A., Belahcen, A., \& Vaimann, T. (2015). Effect of PM parameters variability on the operation quantities of a wind generator. In Proceedings of IEEE Workshop on Electrical Machines Design, Control and Diagnosis (WEMDCD), 26-27 March 2015 (pp. 242-247). IEEE.

3. Ruoho, S., Dlala, E., \& Arkkio, A. (2007). Comparison of demagnetization models for finite-element analysis of permanent-magnet synchronous machines. IEEE Trans. Magn., 43(11), 3964-3968.

4. Ruoho, S., McFarland, J.D., \& Jahns, T.M. (2004). Investigation of the rotor demagnetization characteristics of interior PM synchronous machines during fault conditions. IEEE Trans. Ind. App., 50(4), 2768-2775.

5. Ebrahimi, B.M., \& Faiz, J. (2013). Demagnetization fault diagnosis in surface mounted permanent magnet synchronous motors. IEEE Trans. Magn., 49(3), 1185-1192.

6. Kallaste, A. (2013). Low speed permanent magnet slotless generator development and implementation for windmills. $\mathrm{PhD}$ dissertation, Tallinn University of Technology, Estonia. 


\section{PASTĀVĪGO MAGNĒTU MATERIĀLA MAINĪGUMA IETEKME UZ VĒJA GENERATORA DARBĪBU}

O. Kudrjavtsev, A. Kallaste, A. Kilk, T. Vaimann, S. Orlova

Kopsavilkums

Rakstā tika apskatīta pastāvīgā magnēta materiāla ietekme uz lēngaitas generatora ar pastāvīgajiem magnētiem zudumiem un izejošām raksturlīknēm. Tika noteikts magnēta materiāla mainīgums un tā efekts uz elektriskās mašīnas izejas parametriem. Sešas dažādas neodīmu magnētu pakāpes tika izmērītas un salīdzinātas ar piegādātāja specifikācijas datiem. Rezultāti paradīja, ka magnēta materiālam no dažādiem piegādātājiem ir dažādi raksturlielumi, kas ievērojami ietekmē ǵeneratora izejas parametrus, tādus kā lietderības koeficientu un īpatnējo jaudu.

06.01.2017. 